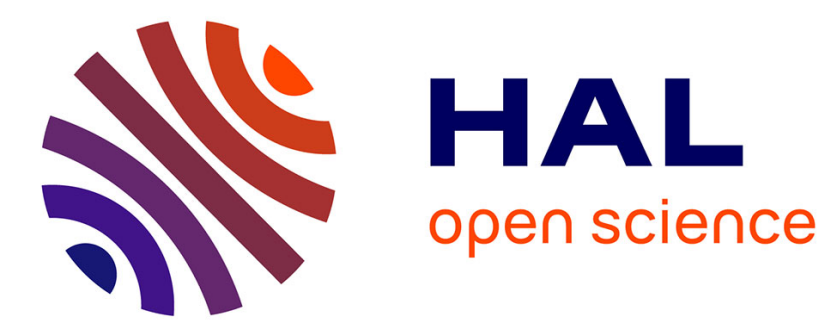

\title{
Metagenomics of the human intestinal tract: from who is there to what is done there
}

Antonietta Cultrone, Julien J. Tap, Nicolas Lapaque, Joël Doré, Herve H. Blottiere

\section{- To cite this version:}

Antonietta Cultrone, Julien J. Tap, Nicolas Lapaque, Joël Doré, Herve H. Blottiere. Metagenomics of the human intestinal tract: from who is there to what is done there. Current Opinion in Food Science, 2015, 4, pp.64-68. 10.1016/j.cofs.2015.05.011 . hal-02632823

\section{HAL Id: hal-02632823 \\ https://hal.inrae.fr/hal-02632823}

Submitted on 27 May 2020

HAL is a multi-disciplinary open access archive for the deposit and dissemination of scientific research documents, whether they are published or not. The documents may come from teaching and research institutions in France or abroad, or from public or private research centers.
L'archive ouverte pluridisciplinaire HAL, est destinée au dépôt et à la diffusion de documents scientifiques de niveau recherche, publiés ou non, émanant des établissements d'enseignement et de recherche français ou étrangers, des laboratoires publics ou privés. 


\section{Metagenomics of the human intestinal tract: from who is there to what is done there Antonietta Cultrone ${ }^{1,2,4,5}$, Julien Tap ${ }^{3,4,6}$, Nicolas Lapaque ${ }^{1,2}$, Joël Doré ${ }^{1,2,3}$ and Hervé M Blottière ${ }^{1,2,3}$}

The human gastro-intestinal tract is colonized by $10^{6}-10^{14}$ microorganisms from the three domains, eukaria, archaea and bacteria that are collectively referred as the human gut microbiota. Gut microbiota actively contributes to the digestion of the nutrients, mainly the fibers otherwise undigested by the host, and participate to the host capacity of energy recovery from food. It plays also a key role in gut homeostasis, impacting on its barrier function and regulating the immune and metabolic systems. The target of this review is the diet-microbiota-host immune response triad. Starting from the current knowledge based on intestinal metagenomics, we point out on the role of food in shaping gut microbiota composition and functions, which is therefore mirrored in its healthful or deleterious effect on host immune response.

\begin{abstract}
Addresses
${ }^{1}$ INRA, UMR 1319 MICALIS, Domaine de Vilvert, Jouy-en-Josas, France

${ }^{2}$ AgroParisTech, UMR Micalis, Jouy-en-Josas, France

${ }^{3}$ INRA, US 1367 MetaGenoPolis, Jouy-en-Josas, France

Corresponding author: Blottière, Hervé M (herve.blottiere@jouy.inra.fr)

${ }^{4}$ Equal contribution.

${ }^{5}$ Present address: Enterome Biosciences, 75011 Paris, France.

${ }^{6}$ Present address: Danone Research, 91120 Palaiseau, France.
\end{abstract}

Current Opinion in Food Science 2015, 4:64-68

This review comes from a themed issue on Foodomics technologies Edited by Alejandro Cifuentes

For a complete overview see the Issue and the Editorial

Available online 3rd June 2015

http://dx.doi.org/10.1016/j.cofs.2015.05.011

2214-7993/C 2015 Elsevier Ltd. All right reserved.

\section{Introduction}

The digestive system is a complex machinery designed for the conversion of food into simple molecules easily absorbed by the different compartments of the human body. It includes the gastrointestinal tract (GIT), which enclose microbial communities, the digestive organs (liver, pancreas), and the digestive enzymes and hormones. The GIT starts from the mouth where food is introduced, mechanically disrupted by mastication and enzymatically degraded by the action of amylases and lipases, and ends up with the anus by which indigested residues are eliminated. Each section of the GIT is responsible for a precise task of the digestive process and is characterized by specific microbial composition, even though Bacteroidetes and Firmicutes account for $90 \%$ of total intestinal microbiota. Only a limited number of bacteria, $10^{1}-10^{3} \mathrm{cfu} / \mathrm{ml}$, mostly Helicobacter pylori, is present in the stomach, mainly because of the acidic environment. In the small intestine the number and diversity of bacterial species gradually increase from duodenum to ileum, which is mainly colonized by Enterobacteria, Bacteroides and Clostridia. The large intestine counts the highest microbial concentration $\left(10^{12}-10^{14} \mathrm{cfu} / \mathrm{ml}\right)$ of the GIT. Most of the bacteria in this section of the digestive tube are strictly anaerobic.

Non degradable food elements, like resistant starches and vegetal fibers are degraded in the large intestine where they undergo fermentation process by resident microbiota [1]. Short chain fatty acid (SCFA), mainly acetate, propionate and butyrate are one of the end products of fiber fermentation and are used by the host as energy source. Indeed, butyrate account for $85 \%$ of the energy needed for colonocytes. The role of SCFA in the prevention of colon cancer or in the promotion of immune tolerance through Treg development has been established [2,3] confirming the key role of diet in shaping gut microbiota composition and promoting either the intestinal homeostasis or the inflammatory associated intestinal dysbiosis.

\section{Metagenomics: a powerful tool to study complex microbial communities}

Metagenomics is a recent approach developed to investigate the human microbiota since most of the microorganisms present in our body are anaerobic and cannot be easily cultivated by classic culture-based methods [4]. Metagenomics consists to isolate genomic DNA from an environmental sample (e.g. stool) for both sequencing and functional analysis. In the last decade, the establishment of international consortia including the EU-funded MetaHIT (Metagenomics of the Human Intestinal Tract) and the US HMP (Human Microbiome project) allowed the generation of an extensive reference catalog of microbial genes present in the human intestine $\left[4,5^{\circ \bullet}\right]$.

The human host is not open to the whole world of bacterial diversity as among more than 50 phyla existing 
in the bacterial world only four phyla represent the dominant human gut microbiota [6,7]. This supposes that strong constraints come into play to condition the gut microbial composition. Evolution, ecology and host environment are such factors.

Comparative studies with hosts phylogenetically distant from human allow understanding how evolution shaped human microbiota. Interestingly, the four main phyla, Firmicutes, Bacteroidetes, Actinobacteria and Proteobacteria, are conserved across mammals [8] where they represent more than $95 \%$ of the microbial count. Selection mechanisms, like anaerobic condition of the intestine, are responsible for the dominance of certain bacteria during gut colonization. At the species levels, the human gut microbiota appears to be quantitatively specific to each individual, which is paradoxical since the main functions (digestive, immunomodulatory and proliferative functions) are conserved among subjects. It has also been observed that some species (mainly Bacteroides and Clostridiales) are shared across subjects constituting a phylogenetic core [9]. The functional core includes genes known to be important to host-bacteria interactions, such as those involved in complex polysaccharides degradation, those necessary to the synthesis of short-chain fatty acids and those necessary to the synthesis of indispensable amino acids and vitamins $[4,10]$. A core microbiota is also found in animals whatever the feeding sources [11].

Dietary habits are probably the most studied factors influencing gut microbiota composition. For instance, it has been shown that, during the first days of life, fecal microbiota composition between breast-fed and formulafed infants was different, breast-fed infants showed a higher concentration of lactic acid bacteria. Among adults, herbivores gut microbiota had in average twice more genera than carnivores (omnivores were intermediate). However, in adults, studies differ considering the ability to modulate the microbiota. $\mathrm{Wu}$ and colleagues showed that only long term diets were able to shape the microbiota [12], while another study demonstrated that diet rapidly and reproducibly alters the human gut microbiome [13]. Meat-based diet increased the abundance of bile tolerant micro-organisms like Alistipes and decreased levels of Clostridiales which are able to metabolize complex plant dietary fibers. The relationship between microbiota, diet and exercise has recently been investigated by Clarke et al. $\left[14^{\circ}\right]$. They observed that professional athletes harbors high microbial diversity (with a higher proportion of Akkermansia genus) than control (non-athletes) and that it is correlated to higher protein intake.

According to Arumugam et al. [15], microbiota can be stratified into at least three assemblages called enterotypes which correspond to a well-balanced host-microbial symbiotic state. Following the enterotype distribution, Western populations could be split into two populations regarding methane production $\left[16,17^{\bullet \bullet}\right]$ reflecting the presence of Methanobrevibacter species. The dominant presence of Methanobrevibacter associated genus Ruminococcus characterizes the enterotype described, which comprise on average, half of the individuals. The two other enterotypes reflect the mutual exclusion between Prevotella and Bacteroides genera. Wu and colleagues showed that Prevotella enterotype could correspond to a long term diet enriched in fibers [12]. In parallel to this observation, other studies showed that African countryside population which have a fiber-rich diet are also Prevotella enriched [18,19].

Age is another factor that shapes microbiota composition. Before birth, human host may be influenced by microorganisms through umbilical cord [20]. A metagenomic study performed on 320 placentas specimens from healthy mothers demonstrated that placenta harbors a unique microbiome related to the oral microbiome, although the biomass is low [21]. During the first month of life, each host acquires a specific microbiota with an increase of species richness. During this period, the number of Actinobacteria decreases with an enrichment of Bacteroidetes and Firmicutes. Birth delivery mode impacts the early composition of gut microbiota. Newborns are naturally enriched with Lactobacillus, the main genera in the vagina microbiota. However, newborns having a C-section delivery display an enrichment in gut microbial species similar to those found on their mother skin microbiota [22 $2^{\bullet \bullet}$. Gut microbiota become mature around the age of three [19]. On the opposite, elderly microbiota is sensitive to lifestyle conditions and an increased number of Proteobacteria is associated with low grade inflammation [23].

\section{Immune response is shaped by gut microbiota and conditioned by diet}

After birth, mucosal surfaces are exposed to a multitude of microorganisms and dietary antigens that constantly stimulate the host immune system (reviewed in [24]). Indeed, microbiota has an essential role in shaping the gut immune system as demonstrated in germ-free mice models characterized by various immunological defects and where administration of polysaccharide A (PSA) from Bacteroides fragilis is sufficient to restore the Th1/Th2 balance, to stimulate Foxp3+ Treg production cells and to protect mice from Helicobacter hepaticus-induced severe colitis $\left[25^{\bullet}, 26,27\right]$. In a similar way, germ-free mice colonized with conventional mouse fecal microbiota or monocolonized with the segmented filamentous bacteria (SFB), show normal Peyer patches development, normal IgA production and normal capacity of CD4+ $\mathrm{T}$ cell differentiation [28].

Under healthy conditions, dietary and microbial antigens are confined in the intestinal lumen. A physical barrier constituted by a monolayer of epithelial cells coated by a thick layer of mucus secreted by goblet cells, avoids direct relationship between bacteria and the 
host connective tissue $\left[29^{\bullet}, 30\right]$. The essential role played by mucins in maintaining a safe environment has been demonstrated using Muc2-deficient mice that present a marked predisposition to generate colitis $\left[29^{\circ}\right]$. A recent report has demonstrated the essential relationship between gut microbiota composition and the properties of the mucus layer with potential implications for health and diseases [31].

Interactions between bacteria and its host are mediated through the recognition of bacterial motifs and antigens by the pattern recognition receptors (PRRs) localized on both the apical and the basolateral side as well as in the endosomes (Toll-like receptors, TLRs), or in the cytoplasme (NOD-like receptors) of epithelial cells (reviewed in $[32,33])$. Bacteria and their antigens can cross the epithelial barrier via the $\mathrm{M}$ (microfold) cells situated in the Peyer's patches to be delivered by transcytosis to the antigen presenting cells situated in the subepithelial dome, or sampled by CX3CR $1^{+}$phagocytes directly in the lumen through the tight junctions [34,35"]. Once antigen is recognized by DCs, these cells migrate to the MLN to prime naïve CD4+ T cells. Epithelial cells are able to regulate DCs functions via the secretion of immunomodulatory molecules. Transforming growth factor-beta (TGF- $\beta$ ) and retinoic acid (RA) are such of these mediators whose secretion is associated to homeostatic conditions through the induction of $\mathrm{CD} 4^{+} \mathrm{Foxp} 3^{+}$Treg [24]. The effect of TGF- $\beta$ has long been associated to those of vitamin A metabolite RA secreted by DCs [36] or by lamina propria macrophages and which is recognized by $\mathrm{RA}$ receptors (RARs) and retinoid $\mathrm{X}$ receptors on CD4+ T cells. Insufficient amounts of dietary vitamin A have been linked to impaired immune response to pathogens probably due to the RA property to stimulate the CD4+ T cells homing capacity [37].

During the last ten years, several studies have focused on the Aryl hydrocarbon receptor (AhR) for its property to regulate immune as well as non-immune cells and to stimulate IL-22 secretion by innate lymphoid cells (ILCs) [38] which, in turn, are involved in the production of antimicrobial peptides as well as in mucus secretion $\left[39^{\circ}\right]$. AhR recognize natural chemicals, food antigens and bacterial metabolites. Dietary tryptophan from cabbage, broccoli and cauliflower is converted in L-kinurenine, an AhR ligand, by the action of Indoleamine 2,3dioxygenase 1 (IDO1). Gut microbiota, especially some Lactobacillus species like L. reuteri and L. johnsonii use dietary tryptophan as energy source and release indole-3aldeyde which in turn activates AhR, stimulate IL-22 transcription and protects mice against Candida albicans colonization (reviewed in [40]). Recently, a screening of a chemical library derived from Propionibacterium freudenreichii, a bacterium isolated from Swiss-type cheese, allowed to identify the 1,4-dihydroxy-2naphthoic acid (DHNA) as an AhR activator in vitro and in vivo models
[41]. Since $A h R$ is down regulated in the intestinal tissues of IBD patients as well as in mouse models of colitis $[42,43]$, its activation by dietary ligands could represent a valuable way to attenuate the symptomatology associated to the disease.

With the aim to decipher the link existing between diet, microbiota and cardiovascular diseases (CVD) and to identify metabolic biomarkers for the early detection of the disease, Wang and colleagues set up a metabolomic study on plasma from healthy and disease individuals [44]. They found that derivatives of dietary phosphatidylcholine and carnitine (from red meat, eggs, among others), notably the trimethylamine oxide (TMAO), are associated to the risk of CVD. TMAO results from choline conversion into trimethylamine (TMA) through enzymes produced by gut microbiota and subsequent TMA oxidation into TMAO by liver flavin monoxygenase. Indeed, Kymberleigh et al., starting from a screening of intestinal bacteria identified eight strains able to generate TMA from choline [45]. Interestingly, no TMAO production has been observed in germ-free mice underlying the important role of gut microbiota.

It is noteworthy that western diet contributes to the development of gastrointestinal diseases. Fiber-rich diet promotes SCFA production by the intestinal microbiota, which, in turn, contributes to maintain intestinal homeostasis. In addition to their contribution to colonocytes energy supply, SCFA action is often associated to the inhibition of lysine or histone deacetylase (HDACs) [2], but they also act as signaling molecules via the interaction with G-protein coupled receptors (GPR) especially free fatty acid receptor 2 (FFAR2/GPR43) and FFAR3/ GPR41, although GPR109A has also been proposed to be involved (reviewed in [46]). The activation of these receptors on epithelial cells, entero-endocrine cells as well as immune cells may be involved in SCFA-dependent effects [3]. Commensal bacteria through their fermentation end products can therefore contribute to protective function. It is noteworthy that Faecalibacterium prausnitzii, a butyrate producing bacteria from Clostridium leptum group, is deficient in intestinal bowel disease (IBD) patients characterized by chronic intestinal inflammation [47], although this intriguing commensal is producing a lot of other metabolites with potential protective activities $\left[48^{\circ}\right.$.

\section{Conclusions}

Large amount of data shows how diet contributes to the composition of intestinal microbiota and, therefore, either to healthy conditions or to the exacerbation of pathologies like IBD, metabolic and cardiovascular diseases. Fate knowledge of nutrients metabolism by intestinal microbiota has allowed the identification of new antigens and the respective receptors on the human host. However, more efforts must be done to better understand how food 
interacts with microbiota and how the latter dialog with the host. To this goal, a multi approach based on the 'Omics' technologies together with in vivo studies and finally human trials are necessary.

\section{Acknowledgements}

This work was supported by Agence Nationale de la Recherche (ANR MicroObes and ANR FunMetaGen), the Metagenopolis Grant ANR-11DPBS-0001, the European Commission FP7 MetaHIT Grant HEALTHF4-2007-201052 and the European Commission FP7 MetaCardis Grant HEALTH-F4-2012-305312.

\section{References and recommended reading} Papers of particular interest, published within the period of review, have been highlighted as:

- of special interest

$\bullet$ of outstanding interest

1. Flint HJ, Bayer EA, Rincon MT, Lamed R, White BA: Polysaccharide utilization by gut bacteria: potential for new insights from genomic analysis. Nat Rev Microbiol 2008, 6:121-131.

2. Blottière HM, Buecher B, Galmiche J-P, Cherbut C: Molecular analysis of the effect of short-chain fatty acids on intestinal cell proliferation. Proc Nutr Soc 2003, 62:101-106.

3. Smith PM, Howitt MR, Panikov N, Michaud M, Gallini CA, Glickman JN, Bohlooly YM, Garrett WS: The microbial metabolites, short-chain fatty acids, regulate colonic Treg cell homeostasis. Science 2013, 341:569-573.

4. Qin J, Li R, Raes J, Arumugam M, Burgdorf KS, Manichanh C Nielsen T, Pons N, Levenez F, Yamada T et al.: A human gut microbial gene catalogue established by metagenomic sequencing. Nature 2010, 464:59-65.

5. Li J, Jia H, Cai X, Zhong H, Feng Q, Sunagawa S, Arumugam M

- Kultima JR, Prifti E, Nielsen T et al: An integrated catalog of reference genes in the human gut microbiome. Nat Biotechnol 2014, 32:834-841

The second catalog of human gut microbial genes derived from metagenomic sequencing of feces from 1267 individuals from three continents and composed of 10 million non-redundant genes.

6. Eckburg PB, Bik EM, Bernstein CN, Purdom E, Dethlefsen L, Sargent M, Gill SR, Nelson KE, Relman DA: Diversity of the human intestinal microbial flora. Science 2005, 308:1635-1638.

7. Suau A, Bonnet R, Sutren M, Godon JJ, Gibson GR, Collins MD, Doré J: Direct analysis of genes encoding 16S rRNA from complex communities reveals many novel molecular species within the human gut. Appl Environ Microbiol 1999, 65:47994807.

8. Ley RE, Hamady M, Lozupone C, Turnbaugh PJ, Ramey RR, Bircher JS, Schlegel ML, Tucker TA, Schrenzel MD, Knight R et al.: Evolution of mammals and their gut microbes. Science 2008 , 320:1647-1651.

9. Tap J, Mondot S, Levenez F, Pelletier E, Caron C, Furet J-P, Ugarte E, Muñoz-Tamayo R, Paslier DL, Nalin R et al.: Towards the human intestinal microbiota phylogenetic core. Environ Microbiol 2009, 11:2574-2584.

10. Turnbaugh PJ, Hamady M, Yatsunenko T, Cantarel BL, Duncan A, Ley RE, Sogin ML, Jones WJ, Roe BA, Affourtit JP et al.: A core gut microbiome in obese and lean twins. Nature 2009, 457:480-484.

11. Omoniyi LA, Jewell KA, Isah OA, Neumann AP, Onwuka CFI, Onagbesan OM, Suen G: An analysis of the ruminal bacterial microbiota in West African Dwarf sheep fed grass- and treebased diets. J Appl Microbiol 2014, 116:1094-1105.

12. Wu GD, Chen J, Hoffmann C, Bittinger K, Chen Y-Y, Keilbaugh SA, Bewtra M, Knights D, Walters WA, Knight R et al.: Linking longterm dietary patterns with gut microbial enterotypes. Science 2011, 334:105-108.
13. David LA, Maurice CF, Carmody RN, Gootenberg DB, Button JE, Wolfe BE, Ling AV, Devlin AS, Varma Y, Fischbach MA et al.: Diet rapidly and reproducibly alters the human gut microbiome. Nature 2014, 505:559-563.

A 16 S ribosomal RNA-based metagenomic study showing that a shortterm diet of animal or plant products impacts on microbial community structure and functions.

14. Clarke SF, Murphy EF, O'Sullivan O, Lucey AJ, Humphreys M,

- Hogan A, Hayes P, O’Reilly M, Jeffery IB, Wood-Martin R et al.: Exercise and associated dietary extremes impact on gut microbial diversity. Gut 2014, 63:1913-1920.

15. Arumugam M, Raes J, Pelletier E, Le Paslier D, Yamada T, Mende DR, Fernandes GR, Tap J, Bruls T, Batto JM et al.: Enterotypes of the human gut microbiome. Nature 2011, 473:174-180.

An initially controversial whole metagenomic sequencing study showing a stratification of human fecal microbiome in at least three clusters named enterotypes.

16. Bond JH Jr, Engel RR, Levitt MD: Factors influencing pulmonary methane excretion in man. An indirect method of studying the in situ metabolism of the methane-producing colonic bacteria. $J$ Exp Med 1971, 133:572-588.

17. Levitt MD, Furne JK, Kuskowski M, Ruddy J: Stability of human

- methanogenic flora over 35 years and a review of insights obtained from breath methane measurements. Clin Gastroenterol Hepatol 2006, 4:123-129.

18. De Filippo C, Cavalieri D, Di Paola M, Ramazzotti M, Poullet JB, Massart S, Collini S, Pieraccini G, Lionetti P: Impact of diet in shaping gut microbiota revealed by a comparative study in children from Europe and rural Africa. Proc Natl Acad Sci USA 2010, 107:14691-14696.

19. Yatsunenko T, Rey FE, Manary MJ, Trehan I, DominguezBello MG, Contreras M, Magris M, Hidalgo G, Baldassano RN, Anokhin AP et al.: Human gut microbiome viewed across age and geography. Nature 2012, 486:222-227.

Comparing the microbiome from a large cohort composed of healthy children and adults in the USA, Amazonas of Venezuela and rural Malawi, this study demonstrates major microbiota changes as a function of age, food and population.

20. Jiménez E, Fernández L, Marín ML, Martín R, Odriozola JM, Nueno-Palop C, Narbad A, Olivares M, Xaus J, Rodríguez JM Isolation of commensal bacteria from umbilical cord blood of healthy neonates born by cesarean section. Curr Microbiol 2005, 51:270-274.

21. Aagaard K, Ma J, Antony KM, Ganu R, Petrosino J, Versalovic J: The placenta harbors a unique microbiome. Sci Transl Med 2014, 6:237ra65.

This study analysed 320 human placenta showing a microbiome niche related to the oral microbiota and associated with history of antenatal infections.

22. Dominguez-Bello MG, Costello EK, Contreras M, Magris M,

- Hidalgo G, Fierer N, Knight R: Delivery mode shapes the acquisition and structure of the initial microbiota across multiple body habitats in newborns. Proc Natl Acad Sci USA 2010, 107:11971-11975.

23. Claesson MJ, Jeffery IB, Conde S, Power SE, O'Connor EM, Cusack S, Harris HM, Coakley M, Lakshminarayanan B, O'Sullivan $\mathrm{O}$ et al.: Gut microbiota composition correlates with diet and health in the elderly. Nature 2012, 488:178-184

A study on the gut microbiota composition of 178 elderly Irish showing a strong association between diet, microbiota structure and health upon aging.

24. Peterson LW, Artis D: Intestinal epithelial cells: regulators of barrier function and immune homeostasis. Nat Rev Immunol 2014, 14:141-153

25. Mazmanian SK, Liu CH, Tzianabos AO, Kasper DL: An

- immunomodulatory molecule of symbiotic bacteria directs maturation of the host immune system. Cell 2005, 122:107-118.

26. Mazmanian SK, Round JL, Kasper DL: A microbial symbiosis factor prevents intestinal inflammatory disease. Nature 2008, 453:620-625. 
27. Round JL, Mazmanian SK: Inducible Foxp3+ regulatory T-cell development by a commensal bacterium of the intestinal microbiota. Proc Natl Acad Sci USA 2010, 107:12204-12209.

28. Lécuyer $\mathrm{E}$, Rakotobe $\mathrm{S}$, Lengliné-Garnier H, Lebreton $\mathrm{C}$, Picard M Juste C, Fritzen R, Eberl G, McCoy KD, Macpherson AJ et al.: Segmented filamentous bacterium uses secondary and tertiary lymphoid tissues to induce gut $\lg \mathrm{A}$ and specific $\mathrm{T}$ helper 17 cell responses. Immunity 2014, 40:608-620.

A study in mice showing SFB ability to induce and stimulate intestina lymphoid tissues that cooperate to generate potent IgA and Th17.

29. Pelaseyed T, Bergström JH, Gustafsson JK, Ermund A,

- $\quad$ Birchenough GM, Schütte A, van der Post S, Svensson F, Rodríguez-Piñeiro AM, Nyström EE et al.: The mucus and mucins of the goblet cells and enterocytes provide the first defense line of the gastrointestinal tract and interact with the immune system. Immunol Rev 2014, 260:8-20.

30. McAuley JL, Linden SK, Png CW, King RM, Pennington HL, Gendler SJ, Florin TH, Hill GR, Korolik V, McGuckin MA: MUC1 cell surface mucin is a critical element of the mucosal barrier to infection. J Clin Invest 2007, 117:2313-2324.

31. Jakobsson HE, Rodríguez-Piñeiro $A M$, Schütte $A$, Ermund $A$ Boysen P, Bemark M, Sommer F, Bäckhed F, Hansson GC, Johansson ME: The composition of the gut microbiota shapes the colon mucus barrier. EMBO Rep 2015, 16:164-177.

A comparison of two mice colonies maintained in separate rooms and displaying different colonic mucus properties that were attributed to differences in their microbiome.

32. Sellge G, Kufer TA: PRR-signaling pathways - learning from microbial tactics. Semin Immunol 2015, 27:75-84.

33. Corridoni D, Arseneau KO, Cifone MG, Cominelli F: The dual role of nod-like receptors in mucosal innate immunity and chronic intestinal inflammation. Front Immunol 2014, 5:317.

34. Chieppa M, Rescigno M, Huang AYC, Germain RN: Dynamic imaging of dendritic cell extension into the small bowel lumen in response to epithelial cell TLR engagement. J Exp Med 2006 , 203:2841-2852.

35. Rescigno M: Intestinal microbiota and its effects on the

- $\quad$ immune system. Cell Microbiol 2014, 16:1004-1013.

36. Coombes JL, Siddiqui KRR, Arancibia-Cárcamo CV, Hall J, Sun C$\mathrm{M}$, Belkaid Y, Powrie F: A functionally specialized population of mucosal CD103+ DCs induces Foxp3+ regulatory T cells via a TGF- $\beta$ - and retinoic acid-dependent mechanism. J Exp Med 2007, 204:1757-1764.

37. Hall JA, Cannons JL, Grainger JR, Dos Santos LM, Hand TW, Naik S, Wohlfert EA, Chou DB, Oldenhove G, Robinson M et al.: Essential role for retinoic acid in the promotion of CD4(+) T cell effector responses via retinoic acid receptor alpha. Immunity 2011, 34:435-447.
38. Kiss EA, Vonarbourg C: Aryl hydrocarbon receptor: a molecular link between postnatal lymphoid follicle formation and diet. Gut Microbes 2012, 3:577-582.

39. Zelante T, lannitti RG, Cunha C, De Luca A, Giovannini G,

- Pieraccini G, Zecchi R, D’Angelo C, Massi-Benedetti C, Fallarino F et al.: Tryptophan catabolites from microbiota engage ary hydrocarbon receptor and balance mucosal reactivity via interleukin-22. Immunity 2013, 39:372-385.

An elegant study showing that tryptophan metabolites impact on mucosal immunity through aryl-receptor dependent IL-22 production.

40. Romani L, Zelante T, De Luca A, lannitti RG, Moretti S, Bartoli A Aversa F, Puccetti P: Microbiota control of a tryptophan-AhR pathway in disease tolerance to fungi. Eur J Immunol 2014, 44:3192-3200.

41. Fukumoto S, Toshimitsu T, Matsuoka S, Maruyama A, Oh-Oka K Takamura T, Nakamura Y, Ishimaru K, Fujii-Kuriyama Y, Ikegami S et al.: Identification of a probiotic bacteria-derived activator of the aryl hydrocarbon receptor that inhibits colitis. Immunol Cell Biol 2014, 92:460-465.

42. Monteleone I, Rizzo A, Sarra M, Sica G, Sileri P, Biancone L, MacDonald TT, Pallone F, Monteleone G: Aryl hydrocarbon receptor-induced signals up-regulate IL-22 production and inhibit inflammation in the gastrointestinal tract. Gastroenterology 2011, 141:237-248.

43. Takamura T, Harama D, Matsuoka S, Shimokawa N, Nakamura Y, Okumura K, Ogawa H, Kitamura M, Nakao A: Activation of the aryl hydrocarbon receptor pathway may ameliorate dextran sodium sulfate-induced colitis in mice. Immunol Cell Biol 2010, 88:685-689.

44. Wang Z, Klipfell E, Bennett BJ, Koeth R, Levison BS, Dugar B, Feldstein AE, Britt EB, Fu X, Chung YM et al.: Gut flora metabolism of phosphatidylcholine promotes cardiovascular disease. Nature 2011, 472:57-63.

45. Romano KA, Vivas El, Amador-Noguez D, Rey FE: Intestinal microbiota composition modulates choline bioavailability from diet and accumulation of the proatherogenic metabolite trimethylamine-N-oxide. mBio 2015, 6:e02481.

46. Tilg $\mathrm{H}$, Moschen AR: Food, immunity, and the microbiome. Gastroenterology 2015, 148:1107-1119.

47. Sokol H, Seksik P, Furet JP, Firmesse O, Nion-Larmurier I, Beaugerie L, Cosnes J, Corthier G, Marteau P, Doré J: Low counts of Faecalibacterium prausnitzii in colitis microbiota. Inflamm Bowel Dis 2009, 15:1183-1189.

48. Miquel S, Leclerc M, Martin R, Chain F, Lenoir M, Raguideau S,

- Hudault S, Bridonneau C, Northen T, Bowen B et al.: Identification of metabolic signatures linked to anti-inflammatory effects of Faecalibacterium prausnitzii. mBio 2015, 6 e00300-15. 